\title{
Peertechz
}

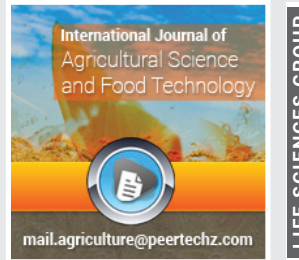

\section{Review of beef cattle breeding research and achievements in Ethiopia}

\author{
Tesfaye Alemu Tucho*, Tatek Woldu and Berhanu Shelima
}

Received: 30 November, 2020

Accepted: 17 March, 2021

Published: 19 March, 2021

*Corresponding author: Tesfaye Alemu Tucho, Adami Tulu Research Center P.O. Box 35, Zeway, Ethiopia, E-mail: talemu1962@yahoo.com

Keywords: Beef cattle breeding; Exotic blood; Indigenous cattle; Research findings

https://www.peertechzpublications.com

Check for updates

Adami Tulu Research Center P.O. Box 35, Zeway, Ethiopia

\section{Abstract}

A literature review was conducted based upon 17 research reports on the beef cattle breeding activities in Ethiopia with an objective of summarizing and compiling research findings in different experiments on breeding works of beef cattle in Ethiopia and indicating future research directions. The review testifies that 27 breeds or types of cattle with 7 distinct breed categories were identified in Ethiopia. The review also summarizes the birth, weaning and yearling weights of indigenous cattle and their crosses at different levels of exotic blood. Conclusions and future research directions were also indicated in this review document.

\section{Introduction}

In Ethiopia there is no specific cattle breed which is exclusively selected and used for beef production, because there has been no development of the indigenous breeds for particular production traits. The indigenous cattle breeds are used for multi purpose traits particularly for milk, meat and draft as well as manure production. The country produces beef in different ways. Major proportion of beef comes from old oxen, culled cows, surplus young bulls and fattened bulls from urban and peri-urban fatteners. Consequently, the major proportion of beef produced in Ethiopia is not of high in quality and quantity.

The country has high potential for beef production. As 40.38 million heads of cattle exists in Ethiopia (CSA 2006). According to FAO, 2003 [1], the cattle population of Ethiopia is around 35 million heads. Moreover, some of the indigenous breeds of Ethiopia like Borana, Horro and Barka are promising in their beef production performances. The big market of the Middle East is not far from the country.

Ethiopia, situated in the horn of Africa, is a country with low level of beef production as compared to other countries in Eastern Africa. Evidences show that level of beef productivity in this country is $110 \mathrm{~kg}$ per head, which is $25-30 \%$ lower than other countries in Eastern Africa and 50\% lower than the world average (212/head) [2]. Likewise, Ethiopia has the lowest level of beef in terms of volume output, which is 27 and $7 \%$ lower than East Africa and the whole Africa, respectively. The less than desirable performance in this sector is mainly attributed to lack of research activities focusing on beef animals, poor nutrition, and low genetic potential of local cattle for beef production and lack of proper fattening system.

In Ethiopia, beef cattle research as separate entity was initiated in 1989, though it was not independently operating as national program until 1997. Therefore, since beef research activities are recently introduced in the Ethiopian Agricultural Research System, sufficient information is not available.

Nevertheless, some institutions including the then Institute of Agricultural Research (IAR), Alemaya University (AU), and International Livestock Research institute (ILRI) and other Agricultural colleges have been carried out limited research in this regard. A notable feature of the entire research effort is the absence of a unified approach and apparent failure to relate lines of research to major problems at the farm level. Until today, there is no ranch or center specialized for breeding for beef animals in Ethiopia. However, among the large variety of indigenous cattle breeds that Ethiopia has, Borana breed are the most popular beef breed identified so far. It is only on Borana cattle breed that relatively intensive study and improvement program have been undertaken.

The current direction of the Ethiopian government is to 
boost beef production and export earning by Improvement of indigenous breeds to attain a desired marketable weight at earlier age. This can be achieved through, selection of indigenous cattle for superior growth performance, cross breeding with appropriate beef breed, improving feed quality and quantity, improving animal health, establishing different cooperatives specialized for rearing, growing and finishing of beef cattle for local and export market.

The objectives of this review paper are:

1. To summaries and compile research findings in different experiment on breeding works of beef cattle in Ethiopia

2. To indicate future research directions in beef cattle improvement.

\section{Methodology}

This review report is based up on PhD Dissertations, MSc theses, proceedings, journals and different research reports. A total of 17 research reports were adequately reviewed to prepare this review report. Summery of the performance of local and crossbreed cattle were made by descriptive statistics such as means and standard deviation.

\section{Result and discussion}

\section{Genetics and breeding}

The recent DARGIS [3], data base report indicated that there are about 27 types\breed of cattle are identified in Ethiopia. They are categorized into 7 distinct breed categories, these are: Small East African Zebu (Adwa, Ambo, Bale, Goffa, Guraghe, Hammer, Harer, Jam-Jam, Jijiga, Mursi, Ogaden zebu, Smada), Sanga (Aliab Dinka, Anuak, danakil, Raya-Azebo ), Zenga (Arado, Fogera, Horo), Large East African Zebu (Arsi, Barka, Ethiopian Borana, Murle ), Hampless Long horn (Kuri), West African Zebu ( Red Fulan) and Humpless Shorthorn (Sheko).

The only beef breeding experiment that can be mentioned is the work carried out by Alemaya College of Agriculture from 1961 to 1967. Beef breeding experiment at Alemaya comprised of crossbreeding of Borana cows with bulls of Hereford, Angus, Charolais, Brahman and Santa Gertrudis. The number of animals born in this program was limited. The results up to 1967 were published by Wagner, et al. [4] and showed that the crossbred calves were $19.6 \%$ higher at birth than Borana Zebu caves $(\mathrm{P}<0.01)$, crossbred calves were $23.6 \%$ higher $(\mathrm{P}<0.01)$ at weaning time (240 days) than were Borana Zebu caves, while in the feedlot, Borana Zebu cattle grew at the rate of $1.74 \mathrm{lb}$ per day as compared to $2.40 \mathrm{lb}$ per day for crossbred cattle, representing a superiority of $37.9 \%$ above the Borana Zebu cattle $(\mathrm{P}<0.01)$. The Angus crossbred calves were the lightest of the different crossbreds at birth and weaning and Charolais crossbred calves were the heaviest. Very recently, there is a plan to evaluate the growth performance, carcass characteristics and other traits of crosses of Borana and Belgian blue beef cattle with different feeding management at Adami Tulu Agricultural Research Center.

\section{Reproductive performance}

The three major traits that contributed to cattle meat production are reproductive performance, viability and growth rate. A high calving rate is essential for profitable calf production and these calves must survive and grow rapidly to obtain satisfactory slaughter weights at early age. Most studies in Ethiopia, however, indicate that reproductive performance of the local cattle is low and inadequate. Information on age at puberty is scanty and widely variable with the crossbred heifers more favorable than Zebu. Environmental factors, particularly nutrition determines pre-pubertal growth rates, reproductive development, onset of puberty and subsequent fertility. For example a study at Abernossa i.e. strategic nutritional supplementation, only in dry season, to young Borana and Borana $\mathrm{x}$ Friesian heifers improved growth rates and reduced age at puberty by about 2 months [5]. A study by Sineshaw (1991) in Debre Zeit indicated a similar observation in Zebu x Friesian crossbred heifers.

Zebu cattle have longer Age at First Calving (AFC) than crossbred (Zebu x Taurine) animals. The differences are partly associated with the difference in management. Improving the management system especially nutrition lowers AFC. For example Studies at Abernossa ranch on Borana heifers, showed the mean age at first calving of 44-54 months to be reduced to 28-30 months through a mere strategic dry season supplementation $[5,6]$. The variation in pregnancy rates in Borana cattle has been attributed to the yearly variation in nutrition (rainfall effect) (Table 1). Provision of supplements in the dry season increased the pregnancy rates of Borana and Borana x Friesian heifers by $15 \%$ (Azage, 1989). The same author in a similar agro-ecological zone reported a difference of $39 \%$ in pregnancy rates between Borana $\mathrm{x}$ Friesian and Borana heifers at 18 months of age. On the other hand, cows calving during the dry season and in poor body condition had pregnancy rates ranging from 22 to $46 \%$ at Abernosa ranch [5].

During periods of adequate nutrition, fertility rates were satisfactory even for zebu cows. For example, at Bako Research Center, a mean calving rate of $93 \%$ was reported for many years [7]. Similarly, in 1989 at Abernosa, when there was good rain, pregnancy rates in Borana cows ranged from 80 to $94 \%$ in four breeding units [5]. Wide variability in pregnancy rates reported for zebu and crossbred cattle suggests genetic, environmental, and management factors can affect herd fertility.

Although Artificial Insemination (AI) practice with proper heat detection methods contribute to the success of $\mathrm{AI}$ operations; year, season, age, and parity of the cow will also contribute to variation in NSC.

Zebu cattle have long calving interval, which influences herd reproductive efficiency and meat production. Economically optimal and practically achievable calving intervals have to be found for different genotypes of cows under different production and management systems.

Aspects of bull reproduction have been totally ignored in 
Ethiopian cattle research and hence, the influence on herd fertility is unknown. However, some studies at Abernossa have indicated that puberty occurred between 16 and 18 months in Borana and rsiabetween 12 and 14 months in Borana $\mathrm{x}$ Friesian bulls and was influenced by dry season nutritional supplementation [5]. The results suggest that reproductive activity in these bulls occurs at earlier ages than was speculated and identification of bulls at younger age for performance testing could be accomplished. Superior bulls in terms of body growth and reproductive capacity therefore could be identified at younger age in order to enhance genetic gains in a selection program.

\section{Growth traits of different genotypes}

Birth Weight (BWT): Early growth traits are important, because it is associated with other performances [8]. Research has shown that higher birth weight followed by faster growth rate in females leads to earlier breeding age and other things being equal, increased lifetime productivity [8].

A comparison of birth weight among the commonly known indigenous cattle breeds of Ethiopia showed that Borana and Barka breeds had almost similar birth weight, but Horro calves were found to be lighter by about $4.49 \mathrm{~kg}(23.8 \%)$ and $3.36 \mathrm{~kg}(19.24 \%)$ than local calves born to Borana and Barka, respectively.

Results of BWT for $\mathrm{F}_{1}$ crosses of Friesian, Jersey and Simmental showed that $\mathrm{F}_{1}$ calves born to Simmental were heavier at birth by $4.82 \mathrm{~kg}(23 \%)$ than $\mathrm{F}_{1}$ calves born to Jersey sire, though dam breed used were the same. Likewise, $\mathrm{F}_{1}$ Friesian calves were heavier by about $3.83 \mathrm{~kg}(18.3 \%)$ at birth than $\mathrm{F}_{1}$ Jersey calves. But there was no difference in birth weight between $F_{1}$ Friesian and $F_{1}$ Simmental calves. This implies that in addition to dam breeds, sire breeds are important sources of variation in BWT (Table 1).

In other studies BWT of calves sired by Friesian bulls were significantly heavier $(\mathrm{P}<0.05)$ than calves sired by

Table 1: Average birth weight of local and crossbred calves in Ethiopia ${ }^{\psi}$

\begin{tabular}{|l|l|l|}
\hline Genotype & Average & Sources \\
\hline Genotypes of calves & & \\
\hline Borana & $23.36(4)$ & Beyene [8], Sendros [9], Hailu [10], Amsalu [11] \\
Horro & $18.87(3)$ & Beyene [8], Sendros [9], Mulugeta [12] \\
Barka & $22.50(3)$ & Beyene [8], Sendros [9], Hailu [10] \\
\hline Average & $21.76(10)$ & \\
\hline$F_{1}$ Friesian & $24.77(12)$ & Kiwuwa, et al. [13], Beyene [8], Ababu [14], Sendros \\
\hline$F_{1}$ Jersey & $20.94(9)$ & [9]. \\
\hline$F_{1}$ Simmental & $25.76(8)$ & Abdinasir [15], Beyene [8], Sendros [9], Hailu [10]. \\
\hline Average & $23.82(29)$ & Beyene [8], Amsalu [11], Hailu and Tadelle [16] \\
\hline$F_{2}$ Friesian & $26.67(7)$ & Abdinasir [15], Beyene [8], Sendros [9] \\
\hline$F_{2}$ Jersey & $22.38(6)$ & Beyene [8], Sendros [9] \\
\hline$F_{2}$ Simmental & $27.05(6)$ & Beyene [8], Sendros [9 \\
\hline Average & $25.37(19)$ & \\
\hline $75 \%$ Friesian & $28.52(5)$ & Beyene [8], Sendros [9] \\
\hline $75 \%$ Jersey & $20.44(5)$ & Beyene [8], Sendros [9] \\
\hline $75 \%$ Simmental & $29.36(5)$ & Beyene [8], Sendros [9] \\
\hline Average & $26.11(15)$ & \\
\hline
\end{tabular}

${ }^{\psi} \mathrm{F}_{1}, \mathrm{~F}_{2}$ and $75 \%$ crosses are crosses with local breeds of Borana, Barka, Arsi and Horro pooled together

Numbers in brackets indicate number of reports from which average values taken
Jersey, Borana, Barka, 1/2Bo1/2F and 1/2Ba1/2J bulls. Calves from Simmental were $4.5 \mathrm{~kg}$ heavier $(\mathrm{P}<0.05)$ than calves sired by Barka. Calves from 1/2Bo1/2J-crossbred sires were $3.7 \mathrm{~kg}$ heavier at birth than purebred Jersey sires. Calves from $1 / 2 \mathrm{Bo} 1 / 2 \mathrm{~S}$ and $1 / 2 \mathrm{Bo} 1 / 2 \mathrm{~F}$ dams were heavier at birth than calves from 1/2Bo1/2J, 1/2Ba1/2J, Borana and Barka dams, but not significantly different from 1/2Ba1/2F calves (Hailu Dadi.2002). The mean body weights of Fogera and their F1 calves were 22.45 $\mathrm{kg}$ and $24.92 \mathrm{~kg}$ at birth respectively ) [17]. Crossbred calves were significantly $(\mathrm{P}<0.05)$ heavier at birth than purebred Borana and birth weights increased with increasing level of Simmental blood (Amsalu Sisay, 2003).

Very little gain was obtained in BWT by inter se mating among $\mathrm{F}_{1}$ crosses and this was expected to be originating from the maternal line. Though it was not for all crosses, higher BWT was obtained as the level of exotic inheritance rose from $0 \%$ to $75 \%$. For instances, an increase in BWT of $4.35 \mathrm{~kg}(20 \%)$ was obtained as the level of exotic inheritance increased from 0 to $75 \%$. Likewise, an increase of about $2.9 \mathrm{~kg}$ (9.6\%) was obtained between $\mathrm{F}_{1}$ crosses and crosses with $75 \%$ exotic inheritance. This suggests that further incorporation of exotic genes beyond $50 \%$ resulted in consistent increase in BWT. In all the reports considered for this review, lower BWT was observed for local Horro calves and crossbred calves born to Horro dams and Jersey sires.

\section{Average Daily Gain (ADG)}

The influences of environmental factors (calf rearing system, housing, feeding, health care etc) are appearing to play influential role in average daily gains of newborn calves. Studies showed that [18], among other factors, calf rearing system (partial suckling or bucket feeding system) plays significant role in affecting average daily gain of calves.

Among the indigenous breeds, under any circumstances, Borana (Bo) calves gained weight faster per day than those born to Barka (Ba) and Horro (Ho) dams. Pre-weaning ADG showed that Bo calves gained $86.57 \mathrm{gm} /$ day $(25 \%)$ and $16.33 \mathrm{gm} /$ day ( $4 \%$ ) faster than local calves born to Ho and Ba dams, respectively. Even though BWT of local calves born to Bo and Ba dams were almost similar, differences appeared in the ADG between the two breeds. This could explain the fact that superiority of Borana breed over the others begins at the early growth traits. Local calves born to Ho dams performed the least in ADG as compared to Ba and Bo calves (Table 2).

Comparison among the crosses showed that $\mathrm{F}_{1}$ Friesian crossbred calves (dam breed consisted of Borana, Barka, and Horro) gained more weight per day than calves born to Jersey and Simmental sires, even though dam breed used were the same. The superiority in ADG of crosses comprised of Frisian sire over crosses comprised of Jersey and Simmental sires were maintained in second-generation and high grades $(75 \%$ exotic inheritance).

Average value showed that local breeds and $\mathrm{F}_{2}$ crosses had similar ADG even though there were large differences in BWT. This could be on one hand attributed to loss of hybrid vigor and

Citation: Tucho TA, Woldu T, Shelima B (2021) Review of beef cattle breeding research and achievements in Ethiopia. J Agric Sc Food Technol 7(1): $133-137$. DOI: https://dx.doi.org/10.17352/2455-815X.000100 
fall in fitness traits in $\mathrm{F}_{2}$ crosses. On the other hand, though there is no hard fact to substantiate it, similar ADG between local and $\mathrm{F}_{2}$ crosses could be attributed to the fact that, though not in all cases, local calves were allowed to suckle their dams while the crosses were reared under bucket feeding system.

Lower average daily gain for $75 \%$ exotic inheritance as compared to $F_{1}$ crosses irrespective of higher BWT is a clear indication of the fact that, under all situations, the level of management that could support optimum ADG for this genetic group was unmet and less than expected performances of high-grades in later life starts at this stage of life.

\section{Weaning Weight (WWT)}

Among local breeds, Borana calves were heavier at weaning by about $19.92 \mathrm{~kg}(24.9 \%)$ and $3.25 \mathrm{Kg}(3 \%)$ than Horro and Barka calves, respectively (Table 3). Large differences in body weight at weaning among local calf breeds could be originated from two possible sources. Firstly, differences in BWT might be attributed to differences in WWT, i.e. calves heavier at birth are also heavier at weaning. Secondly, rate of gain per day is another important source for the difference in WWT i.e. calves, which gain higher per day were heavier at weaning than calves whose daily gain were low.

There was no difference in WWT between $\mathrm{F}_{1}$ Friesian and Simmental calves, but both crosses were heavier than Jersey calves by about $14 \mathrm{~kg}(14 \%)$. A comparison of WWT among $\mathrm{F}_{2}$ crosses showed that $\mathrm{F}_{2}$ Friesian crosses were heavier by about $6.97 \mathrm{~kg}(7.6 \%)$ and $2.73 \mathrm{~kg}(2.8 \%)$ than $\mathrm{F}_{2}$ Jersey and $\mathrm{F}_{2}$ Simmental crosses, respectively. Further comparison of WWT among high grades showed that $75 \%$ Friesian crosses were $16.6 \mathrm{~kg}(18.25 \%)$ and $6.2 \mathrm{~kg}(6 \%)$ heavier at weaning than $75 \%$ Jersey and $75 \%$ Simmental crosses, respectively.

Two breed crosses were heavier by $3 \mathrm{Kg}(6 \%)$ than three breed crosses at the age of 90days. This significant $(\mathrm{P}<0.05)$ weight difference was also reflected in average daily weight

Table 2: Average daily gain (ADG) of different crossbred groups until weaning at six months of age in Ethiopia ${ }^{*}$.

\begin{tabular}{|c|c|c|c|}
\hline $\begin{array}{l}\text { Genotype } \\
\text { calves }\end{array}$ & ADG (gm/day) & $\begin{array}{l}\text { Average } \\
\text { (gm/day) }\end{array}$ & Range (gm/day) \\
\hline $\begin{array}{l}\text { Borana } \\
\text { Barka } \\
\text { Horro }\end{array}$ & $\begin{array}{l}424.1(4) \\
407.77(3) \\
337.53(3)\end{array}$ & $389.8(10)$ & $275(\mathrm{Ho})-490(\mathrm{Bo})$ \\
\hline $\begin{array}{l}\text { Crosses } \\
F_{1} \text { Friesian } \\
F_{1} \text { Jersey } \\
F_{1} \text { Simmental }\end{array}$ & $\begin{array}{l}495.17(7) \\
442.67(6) \\
458.05(6)\end{array}$ & $465.30(19)$ & $\begin{array}{l}450.0\left(F_{1} F \times \mathrm{Ho}\right)-540.0\left(F_{1} F \times B o\right) \\
413.1\left(F_{1} \mathrm{~J} \times \mathrm{Ho}\right)-470.0\left(F_{1} \mathrm{~J} \times \mathrm{Ba}\right) \\
387.5\left(\mathrm{~F}_{1} \mathrm{~S} \times \mathrm{Bo}\right)-520.0\left(\mathrm{~F}_{1} \mathrm{~S} \times \mathrm{Ba}\right)\end{array}$ \\
\hline $\begin{array}{l}F_{2} \text { Friesian } \\
F_{2} \text { Jersey } \\
F_{2} \text { Simmental }\end{array}$ & $\begin{array}{l}399.7(6) \\
383.73(6) \\
384.20(6)\end{array}$ & $389.21(18)$ & $\begin{array}{l}375.4(\mathrm{~F} 2 \mathrm{~F} \times \mathrm{Ba})-430(\mathrm{~F} 2 \mathrm{~F} \times \mathrm{Ba}) \\
358.0(\mathrm{~F} 2 \mathrm{~J} \times \mathrm{Ba})-410(\mathrm{~F} 2 \mathrm{~J} \times \mathrm{Ba}) \\
364.2(\mathrm{~F} 2 \mathrm{~S} \times \mathrm{Ba})-400(\mathrm{~F} 2 \mathrm{~S} \times \mathrm{Ba})\end{array}$ \\
\hline $\begin{array}{l}\text { 75\% Friesian } \\
\text { 75\% Jersey } \\
\text { 75\%Simmenta }\end{array}$ & $\begin{array}{l}437.35(6) \\
391.2(6) \\
389.44(6)\end{array}$ & $406.00(18)$ & $\begin{array}{l}410.0(\mathrm{~F} \times \mathrm{Ho})-490.0(\mathrm{~F} \times \mathrm{Ba}) \\
377.4(\mathrm{~J} \times \mathrm{Ba})-430.0(\mathrm{~J} \times \mathrm{Ba}) \\
324.0(\mathrm{~S} \times \mathrm{Bo})-440.0(\mathrm{~S} \times \mathrm{Ba})\end{array}$ \\
\hline
\end{tabular}

${ }^{\psi}$ ADG $=$ Average Daily Gain

Numbers in brackets indicate number of reports from which average values taken $\mathrm{F}_{1}, \mathrm{~F}_{2}$ and $75 \%$ crosses are crosses with local breeds of Borana, Barka and Horro pooled together
Table 3: Mean WWT of local and crossbred calves at six months of age in Ethiopia ${ }^{\psi}$.

\begin{tabular}{|c|c|c|c|}
\hline Genotype & WWT (kg) & Average (kg) & Range (kg) \\
\hline Borana & $99.92(4)$ & \multirow{3}{*}{$92.2(10)$} & \multirow{3}{*}{$68(\mathrm{Ho})-114.3(\mathrm{Bo})$} \\
\hline Barka & $96.67(3)$ & & \\
\hline Horro & $80.00(3)$ & & \\
\hline
\end{tabular}

Crosses

$F_{1}$ Friesian

113.43(7)

Jersey

$100.00(6)$

$\mathrm{F}_{1}$ Simmental

114.01(8)

109.15(21)

$103\left(\mathrm{~F}_{1} \mathrm{~F} \times \mathrm{Bo}\right)-125\left(\mathrm{~F}_{1} \mathrm{~F} \times \mathrm{Bo}\right)$

$90\left(\mathrm{~F}_{1} \mathrm{~J} \times \mathrm{Ho}\right)-110.4\left(\mathrm{~F}_{1} \mathrm{~J} \times \mathrm{Ba}\right)$

$102\left(\mathrm{~F}_{1} \mathrm{~S} \times \mathrm{Ho}\right)-125\left(\mathrm{~F}_{1} \mathrm{~F} \times \mathrm{Bo}\right)$

$F_{2}$ Friesian 98.6(6)

$F_{2}$ Jersey $\quad 91.63(6)$

$\mathrm{F}_{2}$ Simmental

95.87(6)

$95.37(18)$

95.7 ( $\left.\mathrm{F}_{1} \mathrm{~F} \times \mathrm{Ho}\right)-105\left(\mathrm{~F}_{1} \mathrm{~F} \times \mathrm{Ba}\right)$

88 (F2 J x Ho)-97 (F2 J x Ba)

$93\left(\mathrm{~F}_{2} \mathrm{~S} \times \mathrm{Bo}\right)-99\left(\mathrm{~F}_{2} \mathrm{~S} \times \mathrm{Bo}\right)$

$75 \%$ Friesian

$75 \%$ Jersey

75\%Simmenta

$\left.\begin{array}{l}107.55(6) \\ 90.95(6) \\ 101.35(6)\end{array}\right\}$

101(75\% F x Ho)-119 (75\% F x Ba)

88 (75\% J x Ho)-99 (75\% J x Ba)

98 (75\% S x Ho)-109 (75\%S x Ba)

${ }^{*}$ WWT: Weaning Weight

$F_{1}, F_{2}$ and $75 \%$ crosses are crosses with local breeds of Borana, Barka and Horro polled together

Numbers in brackets indicate number of reports from which average values taken

gain from birth to 90days, where two breed crosses gained 31gm (9.7\%) more weight daily than three breed crosses when all genetic groups are simultaneously considered, $\mathrm{F}_{1}$ crosses were heavier at weaning followed by $75 \%$ exotic inheritances, $\mathrm{F}_{2}$ crosses and local in the order mentioned.

\section{Yearling Weight (YWT)}

At one year of age, $F_{1}$ Friesian crosses were heavier than their Jersey counterparts by about $12.65 \mathrm{~kg}(9.3 \%)$, but lighter than $\mathrm{F}_{1}$ Simmental crosses by about $3.72 \mathrm{~kg}(2.4 \%)$.

The average body weights of Fogera and their F1 calves were $146.8 \mathrm{~kg}$ and $153.3 \mathrm{~kg}$ at one year and $188.9 \mathrm{~kg}$ and $214.1 \mathrm{~kg}$ at two years of age, respectively (Addisu Bitew and B.P Hegede. 2002) (Table 4).

Overall comparison among all genetic groups showed that $\mathrm{F}_{1}$ crosses were heavier than local; $\mathrm{F}_{2}$ crosses and crosses with $75 \%$ exotic inheritances by about $27.67 \mathrm{~kg}(23.34 \%), 14.67 \mathrm{~kg}$ (11.15\%) and $9.36 \mathrm{~kg}(6.8 \%)$, respectively. Though $\mathrm{F}_{1}$ crosses were heavier than crosses with $75 \%$ exotic inheritance and $\mathrm{F}_{2}$ crosses, inferiority of the later genotypes in YWT might be attributed to unmet level of management practices that could support optimum growth in large sized crosses.

Crossbred calves with $50 \%$ Simmental blood had the heaviest $(\mathrm{P}<0.05)$ weight at all ages after birth. Crossing Borana cattle with Simmental breeds improved growth performances of calves with $50 \%$ Simmental blood and further upgrading to $75 \%$ of Simmental blood did not improve growth performance under tropical condition. Male calves were significantly heavier at birth $(\mathrm{P}<0.01)$ and at all other ages $(\mathrm{P}<0.05)$ than female calves, and they grew $6.2 \%$ and $10 \%$ faster than females during pre and post weaning periods, respectively (Amsalu Sisay, 2003).

Borana X Simmental cows had significantly $(\mathrm{p}<0.001)$ the heaviest weight at calving $(381.3 \pm 5.95 \mathrm{~kg})$, estrus $(322.3 \pm 3.07$ $\mathrm{kg})$, service $(330.6 \pm 4.00 \mathrm{~kg})$ and conception $(344.2 \pm 4.56 \mathrm{~kg})$, while Horro cows had the lightest weight. 
Table 4: Average yearling weight (YWT) of local and crossbred calve in Ethiopia ${ }^{\psi}$.

\begin{tabular}{|c|c|c|c|}
\hline Genotype & YWT (kg) & $\begin{array}{l}\text { Average } \\
(\mathrm{kg})\end{array}$ & Range (kg) \\
\hline $\begin{array}{l}\text { Borana } \\
\text { Barka } \\
\text { Horro }\end{array}$ & $\begin{array}{l}128.47(3) \\
120.25(3) \\
106.9(3)\end{array}$ & 118.54(9) & 85.7(Ho)-130.1(Bo) \\
\hline $\begin{array}{l}\text { Crosses } \\
F_{1} \text { Friesian } \\
F_{1} \text { Jersey } \\
F_{1} \text { Simmental }\end{array}$ & $\begin{array}{l}149.28(8) \\
136.35(8) \\
153.00(8)\end{array}$ & $146.21(24)$ & $\begin{array}{l}\left.\text { 142.4( } \mathrm{F}_{1} \mathrm{~F} \times \mathrm{Bo}\right)-160\left(\mathrm{~F}_{1} \mathrm{~F} \times \mathrm{Bo}\right) \\
115.00\left(\mathrm{~F}_{1} \mathrm{~J} \times \mathrm{Bo}\right)-147\left(\mathrm{~F}_{1} \mathrm{~J} \times \mathrm{Bo}\right) \\
144\left(\mathrm{~F}_{1} \mathrm{~S} \times \mathrm{Ho}\right)-175.7\left(\mathrm{~F}_{1} \mathrm{~S} \times \mathrm{Bo}\right)\end{array}$ \\
\hline $\begin{array}{l}F_{2} \text { Friesian } \\
F_{2} \text { Jersey } \\
F_{2} \text { Simmental }\end{array}$ & $\begin{array}{l}134.8(6) \\
129.27(6) \\
129.37(6)\end{array}$ & 131.54(17) & $\begin{array}{l}129(\mathrm{~F} 2 \mathrm{~F} \times \mathrm{Ho})-139(\mathrm{~F} 2 \mathrm{~F} \times \mathrm{Bo}) \\
123(\mathrm{~F} 2 \mathrm{~F} \times \mathrm{Ho})-134.2(\mathrm{~F} 2 \mathrm{~J} \times \mathrm{Bo}) \\
122(\mathrm{~F} 2 \mathrm{~S} \times \mathrm{Ho})-136.4(\mathrm{~F} 2 \mathrm{~F} \times \mathrm{Bo})\end{array}$ \\
\hline $\begin{array}{l}\text { 75\% Friesian } \\
\text { 75\% Jersey } \\
\text { 75\%Simmenta }\end{array}$ & $\begin{array}{l}144.05(6) \\
130.17(6) \\
136.33(7)\end{array}$ & $136.85(19)$ & $\begin{array}{l}\text { 138(75\%J:25\%Ho)-150(75\%:F25\%Bo) } \\
\text { 121(75\%J:25\%Ho)-144(75\%J:25\%Ho) } \\
131(75 \% \mathrm{~J}: 25 \% H o)-141(75 \%: S 25 \% B o)\end{array}$ \\
\hline
\end{tabular}

${ }^{\psi} \mathrm{YWT}=$ yearling weight

$\mathrm{F}_{1}, \mathrm{~F}_{2}$ and $75 \%$ crosses are crosses with local breeds of Borena, Barka, Arsi and Horro polled together

Numbers in brackets indicate number of reports from which average values taken

\section{Conclusion and recommendation}

- Very much limited research activities were undertaken in the country relative to the genetic resources for beef production.

- Appropriate breeding strategies and models should be designed for Improvement of indigenous breeds to attain a desired marketable weight at an earlier age (i.e. either by management, within breed selection or cross breeding with exotic breeds for the intended purpose)

- Future beef cattle breeding activities should consider carcass characteristics, market demand and economic aspects.

- There is no much data on post weaning and matured body weight performance of indigenous cattle or their crosses; generating such data should be considered in the future.

- In addition to the breed improvement programs; enhancing feed quality and quantity as well as prevention and control of animal disease has to be given due attention.

\section{References}

1. FAO (2003) FAO Production Yearbook. 2003. FAO Rome.

2. Beef Research Strategy (1998) Ethiopian beef cattle research strategy document.

3. DAGRIS (2006) Domestic Animal Genetic Resources Information System (DAGRIS). (eds. J.E.O. Rege, W. Ayalew, E. Getahun, O. Hanotte and T. Dessie). International Livestock Research Institute, Addis Ababa, Ethiopia.

4. Wagner OG, Holland GL, Tessera M (1969) Crossbreeding studies with Ethiopian beef cattle using imported semen. East Africa Agric For J 34. Link: https://bit.ly/30Y4uNC
5. Azage T (1989) Reproductive development and function in Zebu and crossbred cattle in Ethiopia. PhD Thesis. James cook University, Australia.

6. Mekonnen HM (1987) Growth and reproductive performance of Boran and crossbred cattle at Abernossa ranch M.Sc. Thesis. Alemaya University of Agriculture, Ethiopia.

7. Gebre - Egziabher GY, Mulugeta K (1996) Fertility of Horro and crossbred cows at Bako Research Center. In: ESAP Proceedings. Fourth National conference of Ethiopian Society of Animal production, 18-19 April 1996, Addis Ababa, Ethiopia.

8. Beyene K (1992) Estimation of additive and non additive genetic effects for growth, milk yield and reproduction traits of crossbred (Bos taurus $\mathrm{x}$ Bos indicus) cattle in the wet and dry environments in Ethiopia. PhD. Thesis, Cornell University. Ithaca, NY. Link: http://bit.ly/3bWNNZ7

9. Demeke S (2002) Genetic Factors Affecting Milk Production, Growth, and Reproductive Traits in Bos taurus $\mathrm{x}$ Bos indicus Crosses in Ethiopia. PhD Thesis. Faculty of Natural and Agricultural Sciences, Department of Animal, Wildlife and Grassland Sciences. University of Free State, Bloemfontein, South Africa. Link: http://bit.ly/3eRxX3X

10. Dadi H (2003) Effects of sire and dam breed genotypes on preweaning traits of calves in indigenous (Boran and Barka) and indigenous $X$ Bos Taurus crossbred cattle. ESAP (Ethiopian Society of Animal Production). Challenges and Opportunities of Livestock Marketing in Ethiopia. Yilma Jobre and Getachew Gebru (Eds). Proc. 10th Annual conference of the Ethiopian Society of Animal Production (ESAP) held in Addis Ababa, Ethiopia. ESAP, Addis Ababa. 407. Link: http://bit.ly/30UGIY3

11. Sisay A (2004) Growth Performance of Boran Cattle and Their Simmental Crosses in Ethiopia. Farm Animal Biodiversity in Ethiopia: Status and Prospects. Asfaw Yimegnuhal and Tamrat Degefa (Eds). Proceedings of the $11^{\text {th }}$ Annual conference of the Ethiopian Society of Animal Production (ESAP) held in Addis Ababa, Ethiopia, August 28-30, 2003. ESAP, Addis Ababa. 441. Link: http://bit.ly/38UA3ML

12. Kebede M (2003) An evaluation of reproductive performance of Horro cattle in Ethiopia. PhD Thesis.

13. Kiwuwa GH, Trail JCM, Kurtu MY, Getachew W, Anderson FM, et al. (1983) Crossbred Dairy Cattle Productivity in Arsi Region, Ethiopia. ILCA Research Report. No.11, Addis Ababa, Ethiopia. Link: https://bit.ly/3lvPFLN

14. Dekeba A (2003) Evaluation of Performance of Ethiopian Boran Cows in the Production of Crossbred Dairy Heifers at Abernosa Ranch. M.Sc. Thesis, Alemaya University, Dire Dawa, Ethiopia.

15. Ibrahim A (1992) Growth performance of crossbred dairy cattle at Asela Livestock Farm, Arsi, Ethiopia. MSc Thesis, Alemaya University, Dire Dawa, Ethiopia 24. Link: http://bit.ly/3r1mbX1

16. Dadi H, Mirkena T (2004) Influence of dam genotype, age of dam and parity on age at first calving, calving interval and birth weight in indigenous and crossbred cattle at Adami Tulu. In: the Proc. of 10th Annual Conference of the Ethiopian Society of Animal Production (ESAP), 21-23 August 2003. Addis Ababa, Ethiopia 223-226.

17. Bitew A, Hegede BP (2003) Reproductive and growth performance of Fogera cattle and their F1 Friesian crosses at Metekel ranch, Ethiopia. ESAP (Ethiopian Society of Animal Production). Challenges and Opportunities of Livestock Marketing in Ethiopia. Yilma Jobre and Getachew Gebru (Eds). Proc. 10 $10^{\text {th }}$ Annual conference of the Ethiopian Society of Animal Production (ESAP) held in Addis Ababa, Ethiopia. ESAP, Addis Ababa. 407. Link: http://bit.ly/3vDDdhv

18. Gojjam Y, Yilma Z, Bekele G, Gebrewold A, Demeke S (2006) Milk yield and reproductive performance of Borana cows and growth rate of their calves under partial suckling method. In: the Proc. of $9^{\text {th }}$ Annual Conference of the Ethiopian Society of Animal Production (ESAP) Addis Ababa, Ethiopia 367377. Link: http://bit.ly/3qWxw15

Copyright: @ 2021 Tucho TA, et al. This is an open-access article distributed under the terms of the Creative Commons Attribution License, which permits unrestricted use, distribution, and reproduction in any medium, provided the original author and source are credited. 